\title{
An Understanding of the Parable of the Shrewd Manager (Luke 16: 1-13)
}

\author{
Olubiyi Adeniyi Adewale \\ Christian Theology Unit, School of Arts \& Social Sciences, National Open University of Nigeria, Lagos.
}

\begin{abstract}
The parable of the shrewd manager or the unjust steward as it has been called by many can be adjudged the most puzzling of Jesus' parables (Fletcher, 1963; Mathewson, 1995; Landry \& May, 2000). The most vexing issue has been the understanding of the steward's reduction of the amount owed his master by the tenants and the following commendation of the servant by the master which is followed by Jesus' comparison of his disciples with the steward who is seen as being fraudulent. The objective of the paper is to arrive at an understanding of the parable in view of the seemingly unpopular strategy adopted by the steward to save himself from future embarrassment. In doing this, the paper looks through ancient practices to understand the actions of the steward and concludes that the actions of the steward can be understood as debt reduction and also highlights the style adopted by Luke in narrating the parable. Through debt reduction, a proven practice is the Mediterranean world, the steward echoes' Jesus mission objective. Through this action, the disciples are called to be faithful in the use of wealth to promote Jesus' objective and not ostentatious living.
\end{abstract}

\section{Introduction}

That the parable of the shrewd manager seems to be the most puzzling of Jesus' parables may be incontestable. This has been confirmed by many scholars. Fletcher opines that "of the recorded parables of Jesus, none has proved to be such a crux interpretationis as the parable of the Unjust Steward" [1]. In the same vein, Mathewson states that, "the parable of the unjust steward in Luke 16: 1-13 is well known for its vexing exegetical difficulties" [2]. Landry and May also said that "almost every article or book section devoted to the so-called parable of the Unjust Steward begins by noting that it is the most difficult of the parables;a whole series of seemingly intractable problem is involved in its interpretation" [3]. Finally, Goodrich has this to say:

The parable of the unjust steward is widely considered the most puzzling of Jesus' teachings. Although a seemingly endless string of interpretations continues to appear in print, no single reading has convinced the current scholarly majority. To be sure, a number of studies in recent decades have offered new and important interpretative insights into the parable, and as a result the number of issues remaining in dispute appears to be on the decline. But, despite these general agreements, the climax of the story remains highly contested among interpreters.... [4].

The objective of the paper is to arrive at an understanding of the parable of the unjust steward in view of the seemingly unpopular strategy adopted by the steward to save himself from future embarrassment. However, unlike most readings from the Eurocentric or Western readings, this article would be examined using the African methodology of interpreting parables ${ }^{1}$, which undoubtedly is closer to the Jewish worldview than the West. Consequently, the most important issues to be addressed are: the context, the characterization, the plot and the use of language.

\section{The Context of the Parable of the Shrewd Manager}

The context of any parable can be subdivided into two, namely: the broad context, which is the socioeconomic condition of the 1st century Palestine and the immediate context, which is the context within which the parable appears in the Gospel. The immediate context would reflect the Gospel writer's use of the parable.

\subsection{The Broad Context}

This parable is set in the social-economic structure of Palestine. It is common to have rich landowners dwelling in the urban setting to appoint a manager who will oversee their investment at home (the rural settings). The manager thus supervises the tenants who are working on the farm and at the time of harvest ensure that the proceeds due to the master are collected. This situation is also similar to the Yoruba context

\footnotetext{
${ }^{1}$ In earlier publications, the African methodology of interpreting parables has been outlined. For a full discussion of this methodology, see Adewale (2004) and Adewale (2006).
} 
where the rich accepts as many tenant farmers to work on his farm land and at the harvest time would send the agreed percentage, either in cash or the actual produce to the landowner. The Yoruba landowners too also appoint an overseer who exercises authority on behalf of the landowner over the tenants.

\subsection{The Immediate Context}

For the immediate context, the parable of the Shrewd Manager belongs to Luke chapter 16 . The indicator for the actual immediate context however cannot be found in 16:1 but in 15:1-3. This is because 16:1

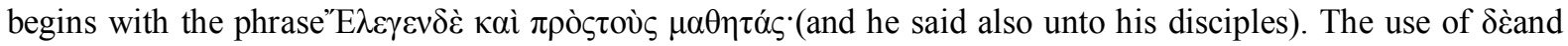
kai together here marks the transition from the parables of 15:4-32 which were directed primarily to the Pharisees and the parable of the shrewd manager (16:1-13) that was directed primarily to the disciples. In Luke 15:1-3, the Pharisees were presented as scorning Jesus for associating with sinners and tax-collectors. The parables of 15:4-32 (the parables of the lost sheep, the lost coin and the prodigal son) were all directed primarily at the Pharisees but with the disciples present as secondary recipients of the parables. For the parable of the shrewd manager, the disciples were the direct recipients (with the Pharisees listening) and their response to this parable elicited the parable of the Rich Man and Lazarus. The Pharisees' criticism of the parable of the Shrewd Managerundoubtedly is related to the intended meaning of the parable. All these nuances are therefore necessary to be noted in a good interpretation of the parable. As Snodgrass notes:

The Parable of the Rich Man and Lazarus in 16:19-31 continues a response of Jesus to the Pharisees, who had scoffed at his warning about money (cf. 16:14). But since the Pharisees in this verse are said to "hear" what Jesus had been saying to the disciples (i.e., the contents of 16:1-13), the implication is that these same "disciples" continue to hear what Jesus says to the Pharisees. Nor does the narrative give us any reason to assume that the customs officers and sinners of 15:1 had departed. Furthermore, the parable contains in roughly equal measure both warning to the rich - including those who, like the Pharisees, while perhaps not overly wealthy, are said to have been "lovers of money" (16:14) - and encouragement to the poor. [5]

This being the case, therefore, the parable would have messages for the groups of people that have formed the audience, either primarily or secondarily. This is why Snodgrass also concludes that:

Luke, therefore, has set these three parables in literary nexuses that highlight their applicability to different groups of people, with these diverse groups evidently serving to represent the whole society in Jesus' day. Jesus warns the crowds - particularly those he speaks of as his "little flock," his disciples - not to fear their poverty or to imitate those who aspire to be rich. Such a warning of itself, however, does not imply a blanket rejection of the rich or the greedy. For in these parables Jesus appeals to them as well as to the poor. [5]

Any interpretation therefore, that would do justice to the parable of the Shrewd Manager must determine, one: the meaning of the parable to the disciples, who were the primary audience; two, what was in the parable that made the Pharisees to scorn Jesus' teachings and lastly, how the rich would have read the same parable.

\section{Characterization}

This parable features three characters, namely: the steward, the master and the master's debtors. Apart from these main characters, the parable continues with Jesus' interpretation, or as some scholars opines, the application of the parable. The characters would be examined at this point. It has to be noted however that all the characters are presented indirectly, that is, the listeners or readers are expected to draw their conclusion about the person of the characters based on their actions and inactions.

\subsection{The Master (Lord)}

The master is the first character to be introduced in this parable. Characteristic of Jesus, he introduced

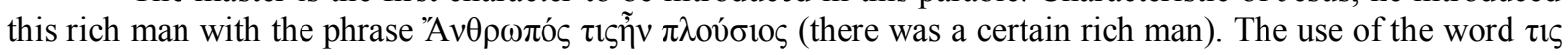
(tis) is very important as it is usually by Jesus to symbolize any one in that class. In other words, the certain rich man could be any rich man. He was also introduced to have a steward or a manager. He heard a report that the manager has wasted or squandered his goods. Based on this report, he summoned the steward and told him to give an account of his stewardship as he has decided to terminate his appointment.

Since the mechanism used in this parable was indirect characterization, the readers has to decide which kind of person the rich man is. The first question that comes to mind is this: what attempt did he make to investigate the allegations made against the steward? This question becomes important when the word used for the allegation is considered. The Greek word used is $\delta \varepsilon \varepsilon \beta \lambda \dot{\eta} \theta \eta$. When the meaning of this word is examined in the lexicons, the following are the meaning: to traduce, calumniate, slander, accuse and defame. [6] Snodgrass also commented on this line when he opines that "linguistically, the balance is slightly in favor of viewing the aorist passive verb dieblethe ("he was accused") as signaling a false or slanderous accusation". [5] Since the preponderance of the meaning of this word suggests malice, can we say that is it possible that the steward was not guilty but was only a victim of malice? How just would then the rich man be to summarily dismiss the 
steward based on mere reports without investigation? This seems to be corroborated by the master's speech in verse 2: "What is this I hear about you?"

To understand this parable, it is necessary to know what prompted the master to dismiss the steward based on malicious report. Pilch and Malina (1993) give an insight into this. This has to do with the honor of the master which at that time in both Jewish and Greco-Roman societies was tied to the master's ability to have firm and good control over the behaviors of every person in his household as this could bring disrepute to the master himself [7]. For example, Landry and May (2000), opine that none of the people in a household, whether slave or freeborn should be allowed to exercise excessive power as their actions will reflect on the master because the master would be considered by the people to be of a character similar to the conduct which they have exhibited or which he failed to correct in them.[3] Apart from this, when issues have to do with finances, the steward has to be seen as an acute and thorough businessman. Thus, the failure of the steward to bring in more profit to his master would not only be seen as the steward's failure but also as dishonor to the master of the steward.

The case is similar in the Yoruba society where the attitude of the people living within the household is seen as the success or failure of the master of the house. For example, a Yoruba proverb says, "oro o dun lenuiyaole" meaning "the mother of a thief has no right of say". This being the case, it can then be argued that the master of the steward dismissed the steward not because of any proven case of fraud or mismanagement but rather the steward's inability to make profits and the master's need to protect his honor. This argument would be taken up later.

\subsection{The Steward}

Apart from the introduction of the master wherein the steward was alleged as being dishonest, the steward was introduced to the listeners or readers through the literary device known as interior monologue. Luke

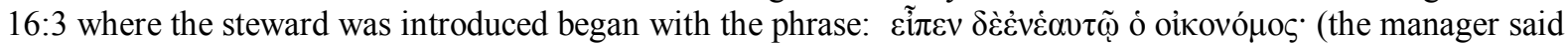
to himself). Before we begin the character sketch of the steward then, it is important to know the device used and the implication. Describing interior monologue as a literary device, Sellew says it is used to give readers or listeners access to the characters' private moments as they think out their plans and strategies. He went further by saying that:

The motivations and personal viewpoints of these actors in the parables are laid bare to give the reader direct access to their unspoken thoughts. The use of this device grants privileged insight into the human dilemma in a fashion not ordinarily available [8]

\section{Through the use of this device, Sellew says:}

The true feelings and inner workings of the characters within these stories are made transparent, not only to the reader but to Luke's other characters as well, who act as the parables' audience within the larger story. This and similar techniques of self-address had long been employed in Greek mimetic or dramatic literature, especially in epic poetry, tragedy, and the Hellenistic novels, as well as in some of the biblical tradition, as a means for an author to paint more vivid and poignant portraits [8].

Other scholars like Walsh (1990) and Halliwell (1990) have also identified interior monologue as a device in classical Greek literature. Having now established that through interior monologue, the readers are allowed to have insight into the true motives of the characters, it could be said that whatever is depicted through the thoughts of the steward is true. The interior monologue is contained in Luke 16: 3-4:

3"The manager said to himself, 'What shall I do, since my master is taking the management away from me? I am not strong enough to dig; I am ashamed to beg. ${ }^{4}$ I know what I shall do, so that when I am removed from the management people will welcome me into their homes.'

From this monologue, two things are immediately clear: one, the steward has no reserve whatsoever and two, he arrived at a plan.

The first truth reflected from the monologue is that the steward might have not been truly guilty of the charges as alleged. This is because, if he had defrauded his master, he would have saved the money for an expected day as this when he would be dismissed. Thinking about future working career is a reflection that losing his job is unexpected which would be strange for a crooked worker. It is also important to know the steward is not admitting laziness but the fact that he is not suited for any other type of work except that of the steward. So, his thought is all about what he can do to keep his job. Corroborating this, Landry and May say that:

The focus of the steward's soliloquy is 'his position.' Since he is losing his position, he wonders what he will do in the future for employment. The purpose of including this speech is to help the hearer understand the steward's subsequent actions. He feels he must do something that will allow him keep his position as a steward-either with his present master or with another-since he cannot do anything else [3] 
However, because the steward knows that if he is being dismissed because he has dishonored his master, no other person would be willing to risk appointing him for the fear of the same treatment. He thus has no option left than to do all he can to keep his present appointment. It is on this basis that the ensuing actions, which were his strategy to keep his job, could be understood.

The second issue is that he arrived at a strategy to resolving the logjam. The strategy was not revealed to us as part of the monologue but as part of the parable itself. Since this is an action taken by the steward, it will also form part of the hearers' opinion of his character. What he did was to call those owing the master and asked them to reduce the amount of what they owed him. How could this then be the way out for him?

Trying to understand the steward's action without a good understanding of the culture and practices of the 1st century Palestine would lead to the kind of misunderstanding that has pervaded the various attempts to interpret this parable. Seeing the reduction of the debts of the tenants as the reduction of unlawful penalties or the steward's commission (Derrett, 1961; Fitzmyer, 1964) cannot explain the issue because firstly, the parable correctly indicates that the money reduced what the entire sum that was owed the master. Apart from this, the rates of the sum reduced, which ranges from $20 \%$ to $50 \%$ were much higher than commission rates (see Kloppenborg, 1989).

Recent researches, however, have shed light on the practice of voluntary debt reduction. Studies in antiquity offers three forms of debt reduction, also called rent remission. The first is called statutory remission, in which case the government would grant a general rent emission to tenants. The second is called obligatory remission, which was granted to farmers who had suffered natural loss of crops (may be due to famine or bad weather). The third, which is similar to the situation described in this parable, is called voluntary rent remission, wherein the landlord would on his own volition grant rent reductions [4].

Though some scholars doubt the veracity of this proposition because they think that the steward cannot take such a decision in behalf of the master, it has to be stated here however, that since the steward has rights to take decision on behalf of the master, granting debt reduction by stewards was not out of place at that time so the actions of the steward can be seen as legal. The next question to ask then is this: how does the plan to grant debt reduction, serve the purpose of the steward?

The future of the steward depends on three possible alternatives:

i. The retention of his current job

ii. A possible appointment elsewhere

iii. Hospitality from the tenants during the looming crisis.

It is obvious that if his scheme was dishonest and fraudulent as many earlier interpretations have assumed, none of the three alternatives would have worked out. Thinking in the same vein, Landry and May say:

We think it unlikely that the steward could be thinking that forgiving those debts would oblige these people to support him gratis forever. The amounts mentioned in the parable (fifty jugs of olive oil, twenty containers of wheat) are large, but not so large that one would think that the debtors would be grateful enough to provide him with a living indefinitely. Moreover, why would the debtors want to hire or harbor a person who had proven himself dishonest and untrustworthy in his previous position? To have any hope of future employment as a manager, the steward needs to salvage his reputation as a good, loyal steward, and the only way he can do this is to take good care of his master, to restore his master's honor. His actions in 16:5-7 are designed to do just this [3].

It has been documented that the use of debt reduction or remission has been prevalent in the $1^{\text {st }}$ century Palestine and it is more to the advantage of the masters rather than to the stewards. Since it has been argued that non repayment of debts on the parts of the tenants on the estate of the master would have been the major crime of the steward, that is, his failure and the linkage of the failure of the master's honor: it follows that any scheme that would remove the non-payment of the debt and restore the master's honor would provide a way out for him. And this is what he achieved through the debt reduction. Commenting on debt reduction, Goodrich says:

...during the early empire partial rent reduction for large-scale landowners in both the western and eastern parts of the Mediterranean (Italy and Egypt) proved to be not only a sensible course of action to secure consistent and long-term profitability, but also a prudent strategy for obtaining debt payment [4].

This being the case, the steward in this parable has demonstrated his ability as an acute and thorough businessman.Describing the possible outcome of the steward's use of debt reduction strategy further, Goodrich has this to say:

... his scheme was profitable for all parties involved. In addition to benefitting the steward and the debtors, the policy also proved advantageous for the master, for it would have created greater dependency between the landlord and his clients as well as stimulated those debtors to repay the remainder of their arrears - and without having either to confiscate pledges or to expel the debtors from his property. The scheme, then, was both honest and prudent, being deserving of both praise from the master and hospitality from the tenants [4]. 
It was the plausibility of the scheme that actually led the master to praise the steward. In using the scheme, he has brought profit to the master, restored the master's honor and went further to present him as magnanimous to the society. This scheme would have also made him appealing to other landlords in case his master failed to reappoint him and also made the tenants hospitable to him (without seeing him as a rogue whom the society must abhor) for the time he would get another appointment. This ingenuity was praised by the master and also by Jesus Christ.

This understanding of the steward's actions as debt reduction is further elucidated by Schellenberg when he opines that the debt relief action of the steward coincides with the objective of Jesus' earthly ministry and it is on the this basis that the commendation was deserved [9]. Schellenberg speaks further:

The expectation within the world of the parable that loyal stewardship requires meticulous collection of the master's debts is confronted with the image of a kúploৎ whose mission is precisely debt release. The master's praise, then, represents the intrusive judgment of the diegetic kóplos concerning the steward's otherwise scandalous debt relief scheme [9].

The problem this would now raise is the resolution of the fcat that the steward is explicitly called 'unjust,' and this is effectively handled in the exposition of Luke's use of a literary device called metalepsis [9]. In this line, Schellenberg concludes that:

the 'unrighteousness' of our steward thus consists not in his willingness to use his master's resources against his metadiegetic master's economic interests; on the contrary, this decision was praised as 'wise' ... the steward is

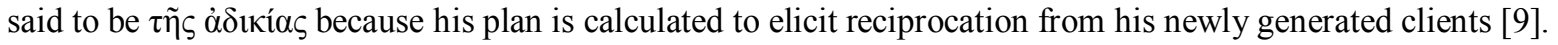

Having removed the complexity of the parable, the next step is to establish the veracity of $16: 8 b-13$.

In the first instance, those who think Luke 16:8b-13 are either not part of the parable proper or see them as Lukan redaction are those who uphold traditional interpretation that the steward was unjust and therefore could not reconcile Jesus' use of the 'dishonest' steward as a role model for the disciples. This position is also recognized by Schellenberg as he states that if the parable is seen as a single level of discourse, then verses $8 b$ to 13 are indeed not appropriate. However, with the new insight into the steward's actions and the use of metalepsis by Luke, the verses "does not represent an attempt to interpret the parable of the Prudent Steward per se; instead these verses guide the hearers through the lively interplay between the parable and its embedding narrative" [9]. The verses should then be seen as follows:

8b-9:

${ }^{8 b}$ for the sons of this age are more shrewd in relation to their own kind than the sons of light.

9"And I say to you, make friends for yourselves by means of the wealth of unrighteousness, so that when it fails, they will receive you into the eternal dwellings.

Through this statement, Jesus acknowledged the ingenuity of unbelievers in their relationship to others. In these verses it is indicated that "the point of comparison between the steward and Jesus' disciples is wisdom and foresight" [2] and faithfulness to the master's cause. By doing this, the verses serve then as a link between the parable and the following application. Thus, unlike other proposition, these verses have to be taken as part of the parable proper. This is why Blomberg (1990) agrees that these verses are used to convey the lessons to be drawn from the main characters of the parable [10].

10-13:

${ }^{10}$ "He who is faithful in a very little thing is faithful also in much; and he who is unrighteous in a very little thing is unrighteous also in much.

${ }^{11}$ "Therefore if you have not been faithful in the use of unrighteous wealth, who will entrust the true riches to you?

12"And if you have not been faithful in the use of that which is another's, who will give you that which is your own?

${ }^{13}$ "No servant can serve two masters; for either he will hate the one and love the other, or else he will be devoted to one and despise the other. You cannot serve God and wealth."

The main lesson Jesus is bringing to his followers is now clear from these verses. This is because the lessons drawn out in these verses are based on an application of the main parable. From the way the verse are structured, it looks as if verses 10-12 belongs together while verse 13 ties up the final conclusion.

It can be concluded that verse 10-12 "center on responsibility with worldly wealth as a test of one's ability to handle true, heavenly wealth" [2]. Since Jesus has already drawn a comparison between the steward and his disciples, this comparison also lies beneath verses $10-12$. It has to be recalled that in v.8b, Jesus has already challenged his disciples that they lack the kind of tact that the steward used in turning a seemingly bad situation to an all-win situation through the use of wealth. It is this lesson that continues here using the concept of the disciple as a steward (definitely of God). In other words, since the Lukan context of this parable has been 
on wealth and the correct use of wealth, as signified in the other two parables in its context (the parable of the rich fool and the parable of the rich man and Lazarus), the same theme is still retained that the disciples are stewards of the wealth they might possessed on earth. It is based on this that the lessons become apt:

a. If the disciples are not faithful in the use of the earthly wealth entrusted to their care, then they cannot be faithful with the true heavenly riches.

b. Unrighteousness in the earthly wealth they are entrusted with can be taken to mean that they will be unrighteous in their use of the true riches and so they might not be trusted with the true riches.

It can then be concluded that Christ expects faithfulness and righteousness in the disciples' use of earthly wealth and it might be a condition for the attainment of true heavenly wealth.

Verse 13 serves as the capstone. The relationship between verse 13 and verses $10-12$ is also the issue of wealth. As Mathewson also opines, "one's use of worldly possessions is an effective test of one's ability to handle eternal reward because it reveals where ultimate loyalties lie" [2] and this is where verse 13 comes in: a disciples loyalties cannot be shared between wealth and God. If his use of wealth pleases God, then that means his ultimate loyalty is to God but if his use of wealth does not please God, it means his ultimate loyalty is to mammon. Through the use of this parable, according to Goodrich:

Jesus illustrates faithfulness both with unrighteous money ( $\dot{\varepsilon} v \tau \tilde{\omega} \alpha \dot{\alpha} \delta i \kappa \omega \mu \alpha \mu \omega v \tilde{\alpha}, \mathrm{v} .11)$ and with that

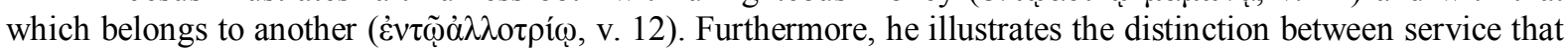

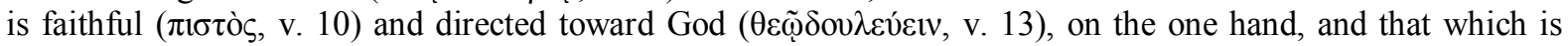

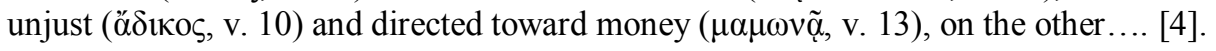

\section{Conclusion}

In summing up the discussion on the parable of the shrewd manager, it is obvious that seeing the action of the steward as that of debt reduction would remove the difficulty earlier interpretation has been grappling with. It has to be noted also that any interpretation that would do justice to the parable of the Shrewd Manager must determine: the meaning of the parable to the disciples, who were the primary audience; what was in the parable that made the Pharisees scorn Jesus' teachings; and how the rich would have read the same parable.

There is no doubt that this parable have relevant implications for the contemporary society in Nigeria. As in Yoruba society, it was argued that the master of the steward dismissed the steward not because of any proven case of fraud or mismanagement but rather the steward's inability to make profits and the master's need to protect his honour. So, this parable brings to fore lessons of stewardship as faithfulness in managing entrusted resources, and a demonstation of love as they relate to the church and society in Nigeria, summarized as follows:

- Like in all Lukan parables involving stewardship, the steward is expected to be faithful to the master. The faithfulness that Jesus praised here is the use of wealth to lead others into freedom from slavery through debt relief. Thus all Christians can be called to use their wealth to pursue the goal of Jesus on earth, bringing the good news to the poor and the release of the captives and the oppressed. Unlike the Pharisees who have misused their position to gain wealth and power and also devour widow's houses, Christians are to engage their wealth in heralding in the Jubilee of the Lord.

- Unlike the steward whose action of debt release was tainted by a selfish motive, the provision of a future for himself, every action of true disciples must be marked by selflessness.

- If Christians would remain true to his allegiance to the Lord, they must put wealth in its proper place. They cannot become a slave to wealth and remain a slave to Jesus Christ. Hence, the church and indeed all Christians must use their wealth to further the interests of the kingdom and not their self-aggrandizement purposes.

\section{References}

[1]. D. R.Fletcher, The riddle of the unjust steward: Is irony the key? Journal of Biblical Literature, 82(1), 1963, 15-30.

[2]. D. L. Mathewson, The parable of the unjust steward (Luke 16:1-13): A reexamination of the traditional view in light of recent challenges. Journal of Evangelical Theological Society, 38(1), (1995), 29-39.

[3]. D. Landry, and B. May, Honor restored: New light on the parable of the prudent steward (Luke 16:1-8a). Journal of Biblical Literature, 119(2), 2000, 287-309.

[4]. J. K. Goodrich, Voluntary debt remission and the parable of the unjust steward.Journal of Biblical Literature, 131(3), $2012,547-566$.

[5]. K. R. Snodgrass, Interpretation of the parables of Jesus. In R. N. Longenecker, (ed.), The challenge of Jesus' parables (Grand Rapids: Wm. B. Eerdmans, 2000), 30-50.

[6]. W. F. Arndt, and F. W. Gingrich,A Greek-English Lexicon of the New Testament (Chicago: University of Chicago Press, 1957).

[7]. J. J. Pilch, and B. J. Malina, (eds). Biblical social values and their meaning: A handbook, (Peabody: Hendrikson, 1993).

[8]. P. Sellew, Interior monologue as a narrative device in the parables of Luke, Journal of Biblical Literature, 111(2), 1992, 239-253.

[9]. R. S. Schellenberg, Which master? Whose steward? Metalepsis and lordship in the parable of the prudent steward (Lk. 16.1-13). Journal for the Study of the New Testament, 30, 2008, 263-288.

[10]. C. L. Blomberg, Interpreting the parables. (Leicester: Inter Varsity Press, 1990). 